\title{
Numerical and experimental research of rock failure mechanism and its dependence on $m_{i}$ Hoek-Brown failure criterion
}

Rudarsko-geološko-naftni zbornik

(The Mining-Geology-Petroleum Engineering Bulletin) UDC: 624.121

DOI: 10.17794/rgn.2021.3.11

Original scientific paper

\author{
Sina Salajegheh'; Kourosh Shahriar ${ }^{2^{*}}$; Hossein Jalalifar ${ }^{3}$; Kaveh Ahangari ${ }^{1}$ \\ ${ }^{1}$ Department of Mining Engineering, Science and Research Branch, Islamic Azad University, Tehran, Iran. \\ ${ }^{2}$ Department of Mining and Metallurgy Engineering, Amirkabir University of Technology, Tehran, Iran. \\ ${ }^{3}$ Department of Petroleum Engineering, Shahid Bahonar University of Kerman, Kerman, Iran.
}

\begin{abstract}
Rock failure mechanism is one of the most important issues in rock mechanics engineering which plays a key role in the stability analysis of various structures. Therefore, different failure criteria have been proposed to understand the failure mechanism of rocks. One of the most commonly used rock failure criteria is the Hoek-Brown criterion, in which there is a parameter called $m_{i}$, which is very important to the response provided by this criterion. Due to the importance of conducting extensive studies on this parameter, in this current research, by performing a series of experimental triaxial compressive strength test and numerical simulating in PFC-2D code, the effect of the Hoek-Brown constant $m_{i}$ on the failure mechanism and crack growth of different rocks has been studied. Based on the results of this study, it was found that the effect of parameter $m_{i}$ on the failure mechanism of different rocks varied according to the type of rocks, and the greatest effect of this parameter was on the peak strength of rocks. In addition, it was found that under higher lateral pressures, there are less destructive cracks in rocks, and as a result, they show more ductile behaviour.
\end{abstract}

Keywords:

Failure Mechanism, Hoek-Brown criterion, $\mathrm{m}_{\mathrm{i}}$ parameter, Triaxial Compressive Strength, PFC-2D.

\section{Introduction}

A great number of rock strength criteria have been proposed over the past years (Hoek and Brown, 1980; Yudhbir et al., 1983; Sheorey et al., 1989; Yoshida, 1990; Ramamurthy, 2001; Dunda et al., 2003; Song et al., 2019). Among the various strength criteria, HoekBrown (HB) strength criterion is one of the most wellknown, which applies to any type of rock and has been used in various aspects of rock engineering (Merifield et al., 2006; Bagheripour and Hakimipour, 2009; Osgoui and Ünal, 2009; Sari, 2012; Shen et al., 2013; Feng and Jimenez, 2015; Bertuzzi et al., 2016; Jiang et al., 2016; Sun et al., 2016; Wu et al., 2017; Peng et al., 2017; He et al., 2020). HB failure criterion is a nonlinear one, which is expressed in terms of major and minor principal stresses at failure $\left(\sigma_{1}\right.$ and $\left.\sigma_{3}\right)$, and the mathematical equation for an intact rock is expressed as follows (Hoek \& Brown, 1980):

where:

$$
\sigma_{1}=\sigma_{3}+\sigma_{c i}\left(m_{i} \frac{\sigma_{3}}{\sigma_{c i}}+1\right)^{0.5}
$$

$\sigma_{1}-$ the major principal stress,

$\sigma_{3}-$ the minor principal stress or confining pressure,

Corresponding author: Kourosh Shahriar

k.shahriar@aut.ac.ir $m_{i}-$ HB material constant,

$\sigma_{c i}$ - the uniaxial compressive strength of the intact rock.

As can be seen in Equation 1, the equation contains two intact rock properties, namely, the uniaxial compressive strength (UCS) of the intact rock $\sigma_{c i}$ and the HB constant $m_{i}$. The values of $m_{i}$ due to its significance in HB failure criterion, have concerned many researchers. Generally, it is assumed that $m_{i}$ is a curve-fitting parameter to achieve the HB failure envelope. However, some research showed that $m_{i}$ is not just a curve-fitting parameter, but has physical meanings which can be derived from micro-mechanics principles (Hoek and Martin, 2014; Zuo et al. 2008, 2015). The values of $m_{i}$ are distributed from 7 to 35 , depending upon the rock material characteristics, however, several factors influence these values. For intact rocks, the $m_{i}$ value varies with the grain size, mineral composition, cementation of rocks, and applied stress (Hoek, 2007). Research by (Singh et al., 2011 and Shen and Karakus, 2014) indicated that the range of the confining stress $\sigma_{3}$ has a significant influence on $m_{i}$ values. In the case of anisotropic intact rocks, the $m_{i}$ value is also influenced by weak planes (Colak and Unlu, 2004; Saroglou and Tsiambaos, 2008; Bagheripour and Hakimipour, 2009; Peng et al., 2014; Perras and Diederichs, 2014; Briševac et al., 2015; Singh et al., 2015; Hoek and Brown, 2019; 
Jafari Mohammadabadi et al, 2021; Wen et al., 2021). Since the $m_{i}$ parameter is very important in the HB strength criterion, it is necessary to conduct comprehensive studies on this parameter. In the present study, an extensive series of experimental Triaxial Compressive Strength (TCS) tests, which follow the ISRM recommendations on three different rock samples, were carried out, and then by an extensive series of numerical simulations, the influence of HB constant $m_{i}$ on the failure mechanism and crack growth of different rocks was studied. Jafari Mohammadabadi et al., 2021 reported that the bond cohesion and tensile strength and friction coefficient are very important to increase rock strength and failure mechanism. As we know, for designing a safe and stable underground or surface mining project, rock failure mechanism and failure criterion are the most important issues which should be understood clearly. So, rock failure criteria's parameters such as $m$ and $s$ in the Hoek-Brown failure criterion should be defined, otherwise, it may affect the stability, and finally, a collapse could occur. For this reason, in this current research, three types of rock were selected and rock failure mechanism and crack initiation were evaluated, both experimentally and numerically. In numerical simulations where the effects of micro-parameters were not taken into account, the simulations were precisely analyzed and then the results were compared with experimental tests.

\section{Material and methods}

To conduct the studies, three types of rock samples, namely andesite, limestone and sandstone have been tested, which include rocks with different strength values. Altogether, 27 rock samples were tested. Numerical simulations have been performed using particle flow code 2D (PFC2D). This code, which is one of the most famous software based on the Discrete Element Method (DEM), simulates the materials as a set of bonded particles that follow the law of motion. In PFC2D, the constitutive relations have been replaced with simpler particle contact logic (which do not require plasticity rules), and so there is no need for pre-defined complex empirical relationships (Bahrani et al., 2011). Also, all stages of fracture mechanism could be simulated (from crack initiation, propagation, to coalescence explicitly with bond breakage) without any specific crack-criteria (Zhang and Stead, 2014).

Due to its advantages, PFC2D has been used in a wide range of numerical studies by other researchers in recent years (Hama et al., 2017; Calvetti, 2008; Gu et al., 2017; Lin et al., 2017; Akram and Sharrock, 2010; Cui et al., 2019; Potyondy and Cundall, 2004; Asadi et al., 2012; Bahaaddini et al., 2013; Bahaaddini et al., 2014; Bahaaddini et al., 2016; Bahaaddini, 2017; Yang and Huang, 2018; Deisman et al., 2010; Mas Ivars et al., 2011; Bahaaddini et al., 2013b; Bahaad-

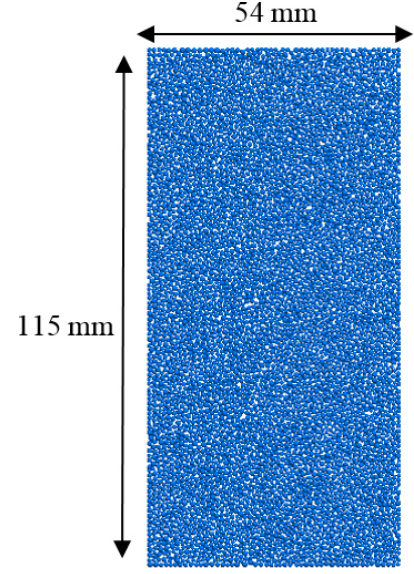

Figure 1: Geometry of PFC 2D model in TCS test

dini et al., 2016; Jiang et al., 2018; Jafari Mohammadabadi et al., 2021).

PFC2D code has three main bonding models (Contact Bond (CB), Parallel Bond (PB), and Flat-Joint (FJ) models) that simulate the cementation between particles. In the current study, the FJ model is used for numerical modeling. This model was proposed by Potyondy (2012) to fix the intrinsic problems that had been raised in the standard PB model and can reproduce the mechanical behaviour of rock materials under different loading conditions (Bahaaddini et al., 2019; Jafari Mohammadabadi et al., 2021).

In this research, the diameter and height of samples were considered $54 \mathrm{~mm}$ and $115 \mathrm{~mm}$, respectively (see Figure 1). In the process of generating a sample, as the first stage, a sample vessel including frictionless walls was created, and then it was filled with a set of particles that were placed randomly. The particle size obeys a normal distribution which is determined by the minimum particle radius $\left(\mathrm{R}_{\min }=0.45 \mathrm{~mm}\right)$ and the ratio of maximum to the minimum radius $\left(\mathrm{R}_{\max } / \mathrm{R}_{\min }=1.5\right)$. For decreasing the number of locked-in stresses, isotropic stress is applied between all of the particles through the grain scale processing. Finally, bonds are installed at the particle contacts with a gap equal to or less than the installation gap (Itasca Consulting Group Inc., 2017).

After the generation of specimens, the micro-properties of particles and bonds must be calibrated. To perform the calibration process in PFC2D, the mechanical properties of the synthetic material, i.e. the macro response of its behaviour, must be set up, and then microproperties are defined and calibrated with an appropriate method depending on the bond type used in the model. Both uniaxial and triaxial compressive strength tests can be modeled during the calibration process (Itasca Consulting Group Inc., 2017). Therefore, the mechanical behaviour of the synthetic samples under the compression test is reproduced and compared with the experimental tests. In this paper, the TCS test has been used for calibrating the micro-properties of synthetic samples. 


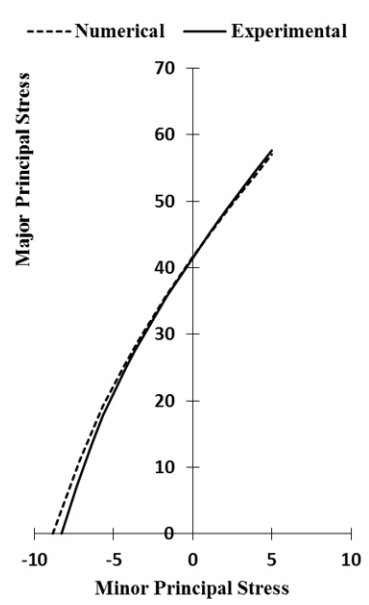

(a) Andesite

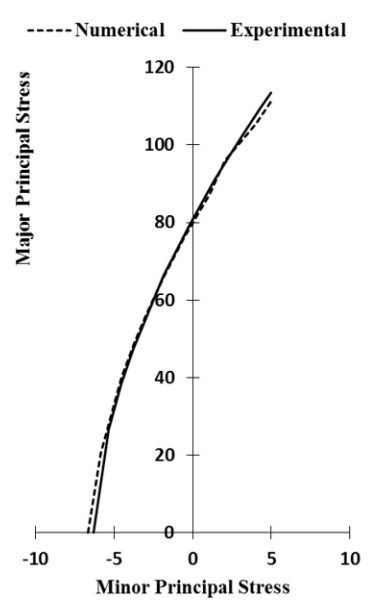

(b) Sandstone

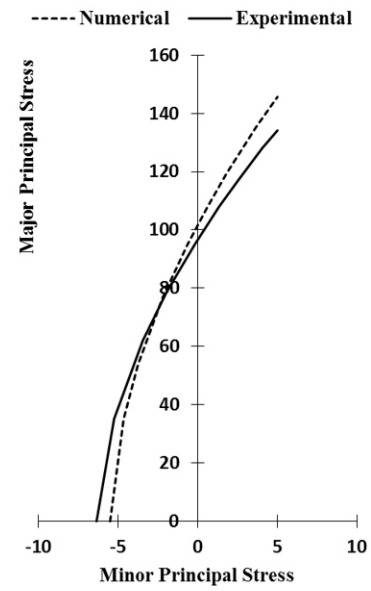

(c) Limestone

Figure 2: Comparison of failure envelope of numerical and laboratory tests
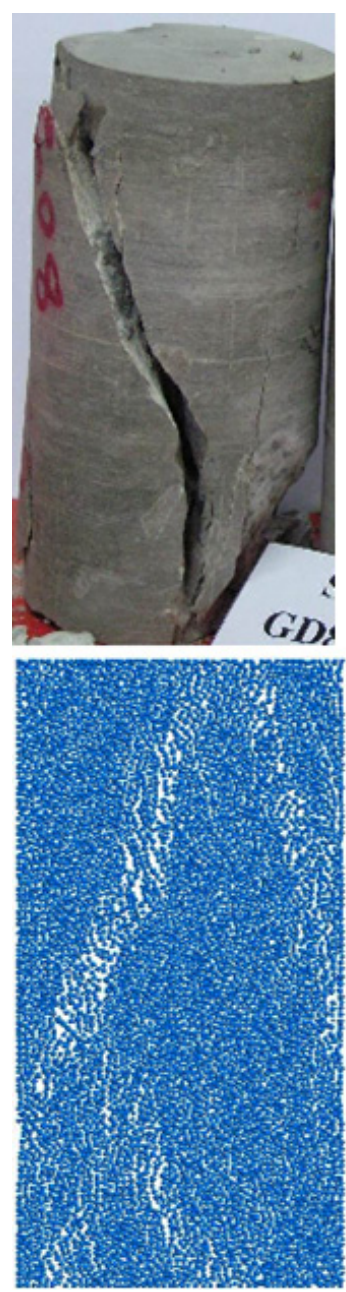

(a) Andesite
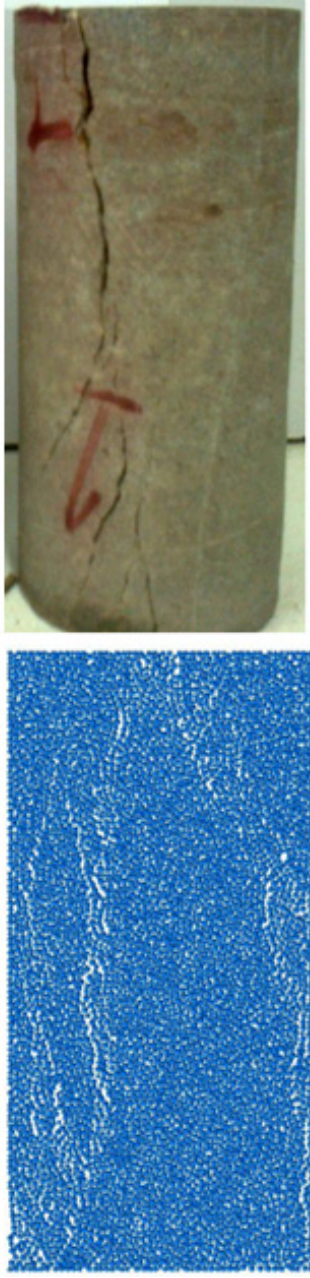

(b) Sandstone
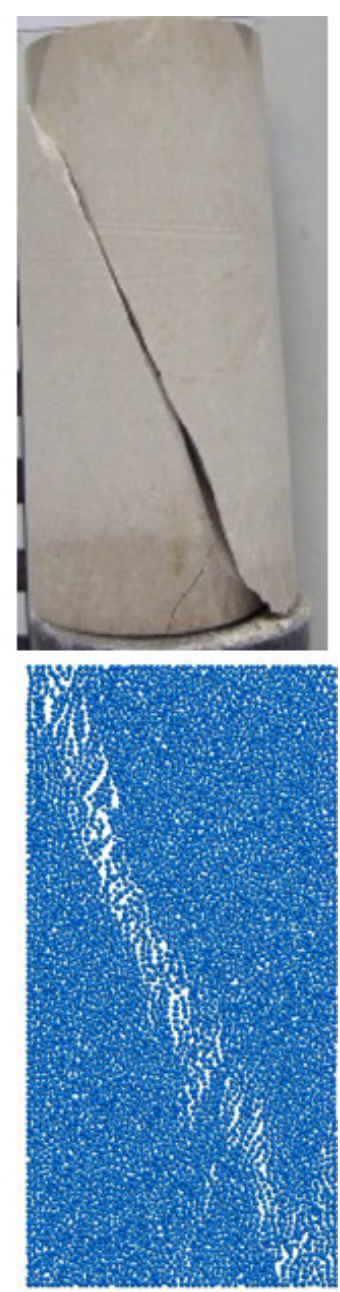

(c) Limestone

Figure 3: Comparison of failure platen of numerical and laboratory tests

To ensure the accuracy of the numerical results, the failure envelopes of the rock samples have been compared with laboratory tests, which are shown in Figures 2 and 3. Also, in Table 1, the values of rock strength parameters in both numerical and laboratory modes are compared with each other. According to Figures 2 and $\mathbf{3}$, and Tables $\mathbf{1}$ and $\mathbf{2}$, the values obtained from numerical models are very close to the laboratory in all three 
Table 1: Comparison of numerical and experimental results

\begin{tabular}{|c|c|c|c|c|c|c|c|c|c|}
\hline \multirow[b]{2}{*}{ Rock } & \multicolumn{3}{|c|}{$\mathbf{m}_{\mathrm{i}}$} & \multicolumn{3}{|c|}{$\mathrm{C}$ (MPa) } & \multicolumn{3}{|c|}{$\Phi\left(^{\circ}\right)$} \\
\hline & Experimental & Numerical & $\begin{array}{l}\text { STD } \\
(\%)\end{array}$ & Experimental & Numerical & $\begin{array}{l}\text { STD } \\
(\%)\end{array}$ & Experimental & Numerical & $\begin{array}{l}\text { STD } \\
(\%)\end{array}$ \\
\hline Andesite & 5.00 & 6.47 & 2.94 & 12.35 & 12.42 & 0.56 & 31.40 & 35.22 & 12.16 \\
\hline Sandstone & 12.86 & 12.04 & 6.37 & 17.30 & 18.99 & 9.76 & 46.86 & 45.83 & 2.19 \\
\hline Limestone & 15.25 & 17.96 & 17.77 & 17.29 & 17.9 & 3.52 & 49.57 & 51.94 & 4.5 \\
\hline
\end{tabular}

*STD: standard deviation

Table 2: Average value of principal stresses on each sample

\begin{tabular}{|l|c|c|c|c|c|c|c|c|c|c|}
\hline \multirow{2}{*}{$\begin{array}{l}\text { Rock } \\
\text { number }\end{array}$} & \multicolumn{3}{|c|}{ Andesite } & \multicolumn{3}{c|}{ Limestone } & \multicolumn{3}{c|}{ Sandstone } \\
\cline { 2 - 12 } & Ave.S*1 & Ave.S2 & Ave.S3 & Ave.S1 & Ave.S2 & Ave.S3 & Ave.S1 & Ave.S2 & Ave.S3 \\
\hline$\sigma_{1}(\mathrm{MPa})$ & 47.3 & 53.3 & 60 & 102.7 & 113.1 & 132.2 & 94.2 & 106.3 & 119.8 \\
\hline$\sigma_{3}(\mathrm{r})$ & 1 & 3 & 5 & 1 & 3 & 5 & 1 & 3 & 5 \\
\hline
\end{tabular}

*Ave.S = Average for each sample

Table 3: Calibrated values from each rock in PFC $2 \mathrm{D}$ models

\begin{tabular}{|l|l|l|l|l|}
\hline Property & Andesite & Limestone & Sandstone & Unit \\
\hline Density & 2450 & 2600 & 2450 & $\left(\mathrm{~kg} / \mathrm{m}^{3}\right)$ \\
\hline $\begin{array}{l}\text { Bonded } \\
\text { fraction }\end{array}$ & 0.93 & 0.98 & 0.99 & --- \\
\hline Ec & 6.0 & 15.2 & 14.0 & $(\mathrm{GPa})$ \\
\hline $\mathrm{K}_{\mathrm{n}} / \mathrm{K}_{\mathrm{s}}^{*}$ & 1.7 & 2 & 1.7 & --- \\
\hline $\begin{array}{l}\text { Friction } \\
\text { coefficient }\end{array}$ & 0.45 & 0.8 & 0.3 & --- \\
\hline Cohesion & 33.5 & 64.5 & 82.0 & $(\mathrm{MPa})$ \\
\hline Cohesion std & 3.35 & 6.45 & 8.2 & $(\mathrm{MPa})$ \\
\hline $\begin{array}{l}\text { Tensile } \\
\text { strength }\end{array}$ & 5.0 & 12.6 & 4.5 & $(\mathrm{MPa})$ \\
\hline $\begin{array}{l}\text { Tensile } \\
\text { strength std }\end{array}$ & 0.5 & 1.26 & 0.45 & $(\mathrm{MPa})$ \\
\hline Friction angle & 5 & 15 & 5 & Degree \\
\hline
\end{tabular}

* Kn and Ks are normal and shear stiffness between grains respectively

rock samples. Therefore, it can be concluded that the created models are sufficiently accurate to perform more research. The calibrated micro-parameter values from each rock type are given in Table 3. As shown in Figure $\mathbf{2}$, the maximum principal stress versus minimum principal stress is drawn based on Hoek-Brown rock failure criterion. Even though andesite and sandstone have a lower value of $m_{i}$ compared to limestone, they are more brittle and axial and tensile fractures were developed through the samples, despite the low value of their strength. Limestone is denser and stiffer than the other samples. As it was found from both experimental and numerical simulations, a major fracture is developed rather than some wing cracks and micro fractures, which shows a higher rigidity of the rock. In addition, it is also because of calibration accuracy in PFC, andesite and sandstone have a high compatibility, while for limestone, the scatter between the graphs is slightly increased. This small amount may be ignored.

\section{Results and discussion}

After the calibration process and ensuring the accuracy of numerical results, the effect of the $m_{i}$ parameter on the mechanical properties of the rocks was studied. For this purpose, first, the behaviour of stress-strain curves of all three rock types under a confining pressure of $3 \mathrm{MPa}$ was studied. The graphs of these results are shown in Figure 4.

As can be seen in Figure 4, the obtained stress-strain curves for andesite, sandstone and limestone are shown. The andesite rock reached its peak of strength after withstanding $0.95 \%$ strain at a stress of $60 \mathrm{MPa}$ and then failed. In this rock, tensile cracks with 91 percent of total cracks had the most influence on the failure mechanism and the rock had a linear behaviour. The first crack (which is a tensile one) was created at a stress of 9.9 $\mathrm{MPa}$ and around $0.2 \%$ strain and the destructive cracks started at 53.9 MPa. However, shear cracks started around $0.8 \%$ strain, which started four times later than the tensile cracks.

In sandstone, after withstanding $0.79 \%$, the rock reached peak strength at $114 \mathrm{MPa}$. This rock has shown brittle behaviour. Also, tensile cracks have the greatest impact on the failure of the rock sample (99\% of total cracks), and the crack density suddenly increased from the moment of $\sigma_{\text {peak }}$ to the moment of sample failure. In this sample also, shear cracks started at $0.8 \%$ of strain while the tensile cracks started at less than $0.2 \%$ of strain.

In limestone, the rock sustained a $0.90 \%$ strain, and then at a stress of $132 \mathrm{Mpa}$, it reached the peak of its 


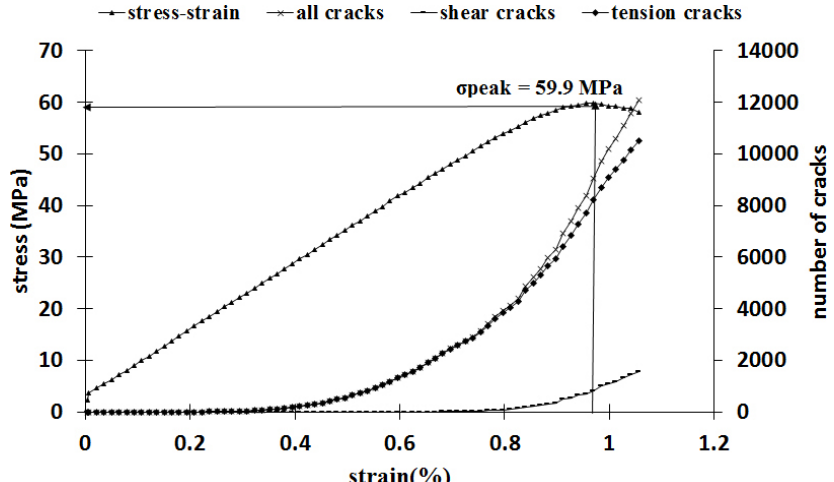

(a) Andesite

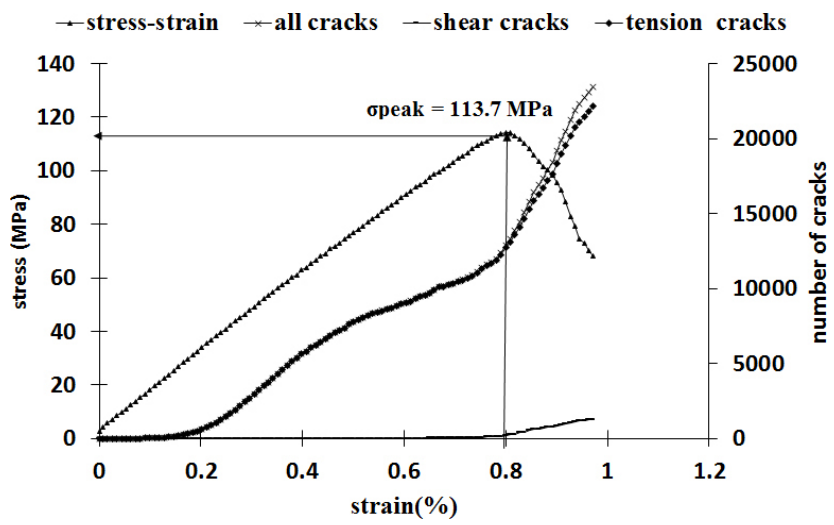

(b) Sandstone

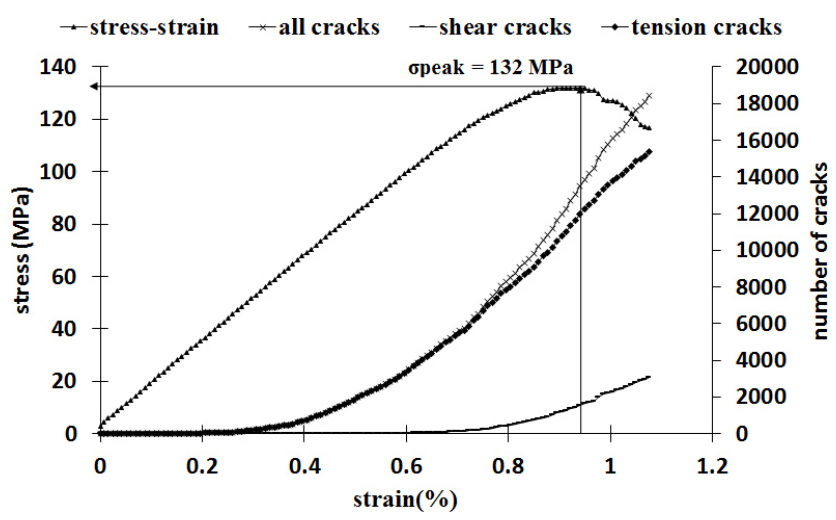

(c) Limestone

Figure 4: Obtained stress-strain curves for (a) andesite (b) sandstone (c) limestone

strength. This rock had a ductile behaviour and tensile cracks have the most influence on the failure mechanism ( $91 \%$ of total cracks). In this rock type, tensile cracks started around $0.3 \%$ of strain but shear cracks began at $0.6 \%$ of the strain value.

In Figure 5, a comparison of the mechanical responses in each rock sample under different lateral pressures is shown. The mechanical response of these three rock samples has been coordinated under different lateral pressures. In these graphs, the values of the ultimate strength of rocks and the equivalent strain are researched. According to the following diagrams, it can be seen that limestone (which had a larger $m_{i}$ ) has greater strength

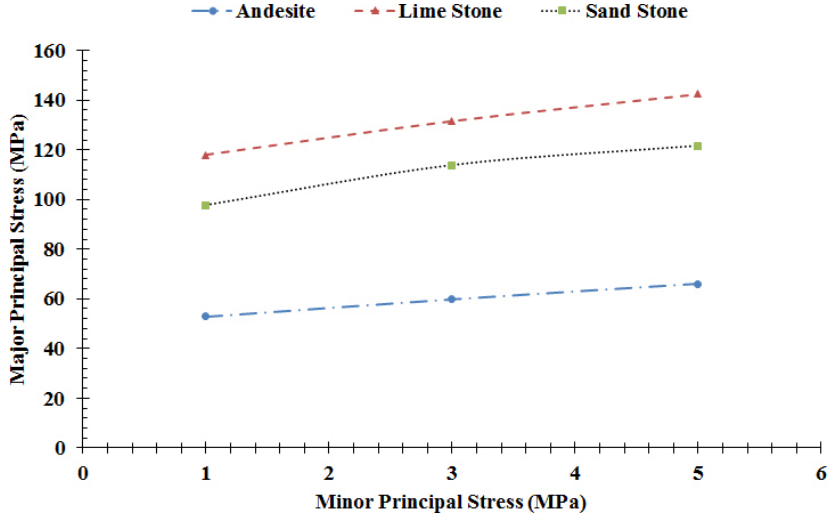

(a) Stress

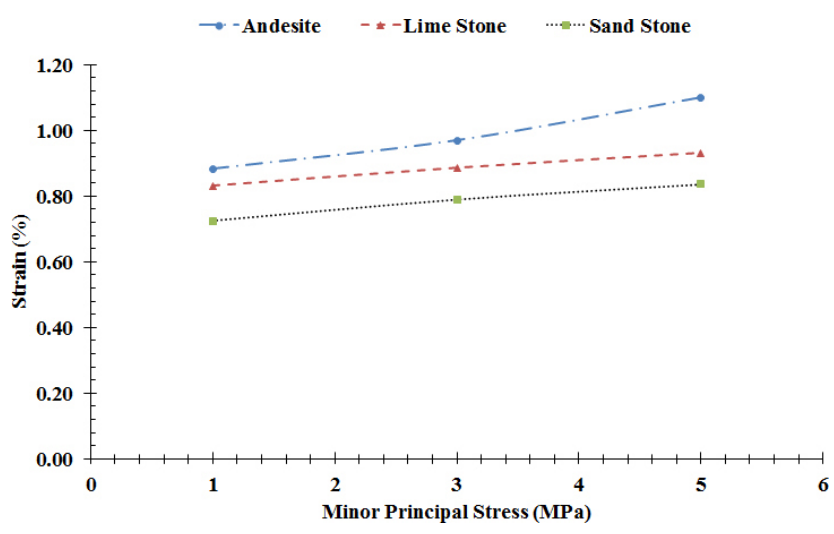

(b) Strain

Figure 5: Comparison of the mechanical responses in each rock sample under different lateral pressures: (a) stress (b) strain

than the other two rocks. This relation is consistent in the two other rocks as well. The strain values of the rocks in andesite (which had a smaller $m$ ) were higher than in the other cases. However, in the other two rock samples, this relationship was not consistent, and limestone withstood more strain than sandstone.

Also, the density of destructive cracks at the moment of $\sigma_{\text {failure }}$ and $\sigma_{50}$ has been studied, which is shown in Figure 6. According to Figure 6, the density of cracks at the moment of failure in andesite rock is less than the other rocks, but limestone had fewer cracks than sandstone, and this density decreased with the increasing lateral pressure in all three types of rocks. These relations were also consistent at the $\sigma_{50}$ of all 3 rock types. However, the density of destructive cracks in sandstone is much higher than in the other rocks.

Moreover, the condition of the specimen samples at the time of failure under different lateral pressures is also shown in Figure 7. According to Figure 7, it can be seen that the andesite rock has a shear fracture, which becomes more visible with increasing lateral pressure. Also, sandstone and limestone have splitting and multiple shear fractures, respectively. The tensile cracks (indicated by red balls) had the greatest impact on the failure mechanism in all three cases of these rock samples, 


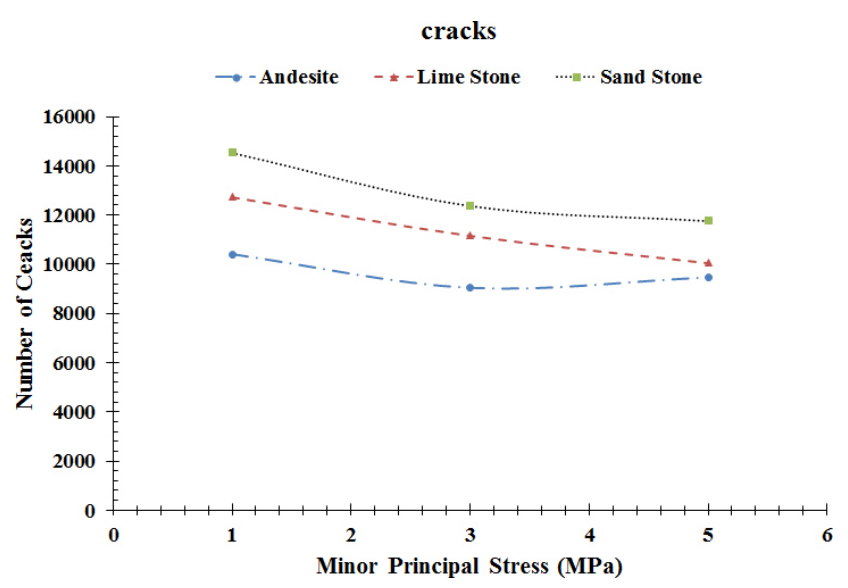

(a) $\sigma_{\text {failure }}$

cracks

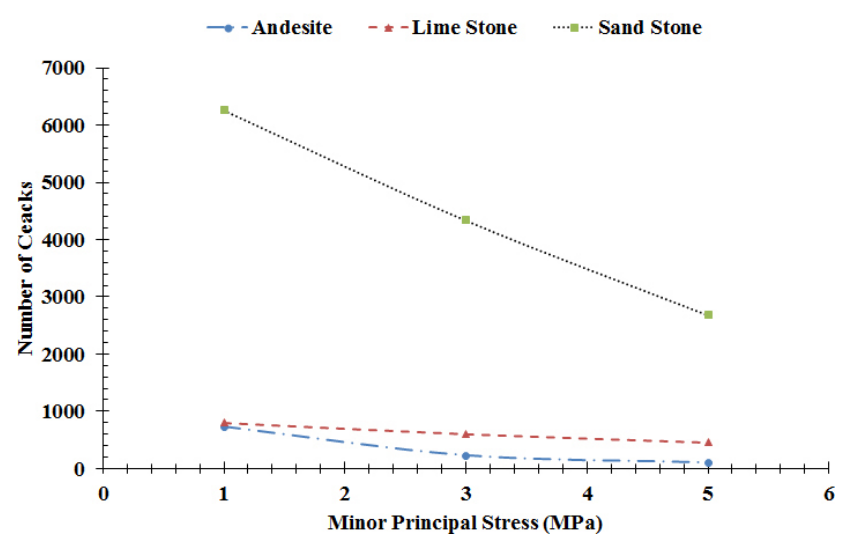

(b) $\sigma_{50}$

Figure 6: Comparison of the density of destructive cracks in rock samples under different lateral pressures: (a) At $\sigma_{\text {failure }}$ and (b) At $\sigma_{50}$

and with increasing lateral pressure in all three cases, the behaviour of the rock has become more ductile.

\section{Conclusion}

In this paper, using experimental tests and numerical simulations of Triaxial Compressive Strength tests in PFC 2D software, and the effects of the HB parameter $m_{i}$ on the mechanical behaviour of three rock types with different mechanical properties and failure mechanisms were studied. For this purpose, after ensuring the accuracy of the numerical results compared to experimental results, the stress-strain curves of the rocks and the macro responses of their behaviour were studied. The most important results of this study can be summarized as follows:

According to the studies, it was found that the effect of parameter $m_{i}$ on the failure mechanism of different rocks varied according to the type of rocks. However, the greatest effect of the $m_{i}$ parameter was on the ultimate strength of rocks so that the lowest change in its value can change the amount of ultimate strength of the rocks. Increasing this parameter reduces the value of
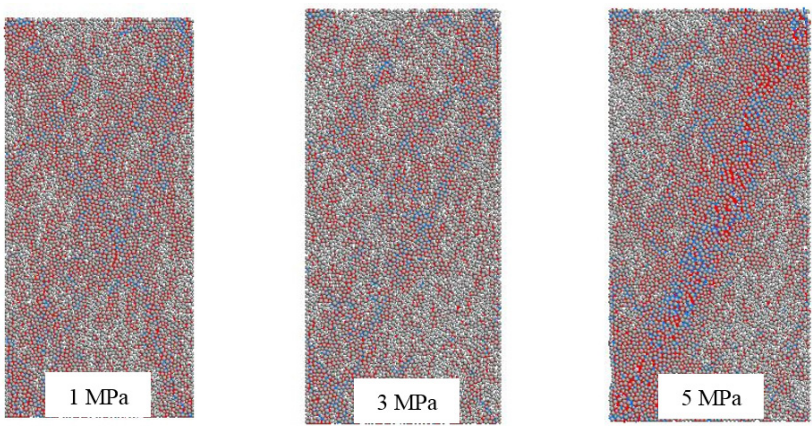

(a) Andesite
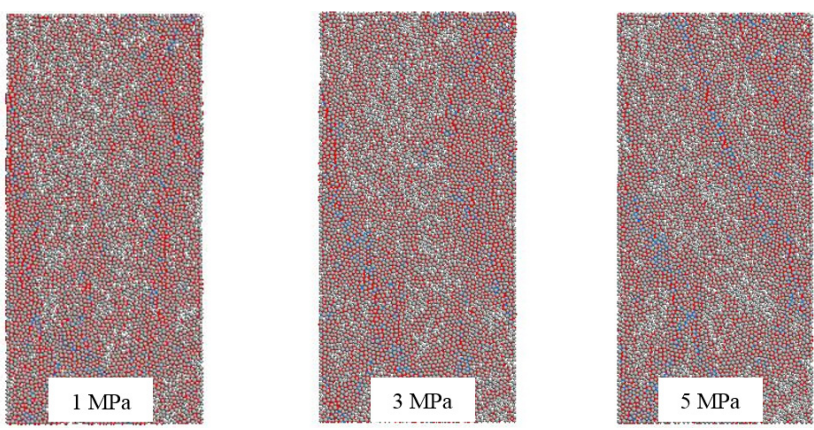

(b) Sandstone
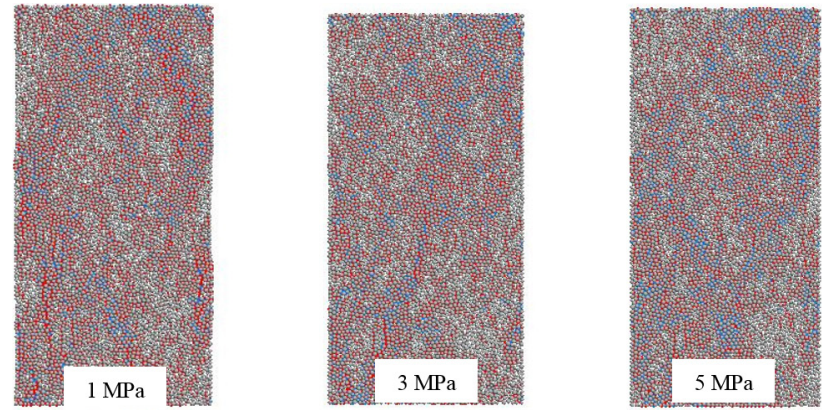

(c) Limestone

Figure 7: Condition of shear and tensile cracks in rock samples under different lateral pressures: (a) andesite (b) sandstone (c) limestone

strains that occurred depending on the type of rock. This could change the rock behaviour dramatically if the right value could not be taken into account. In addition to this, increasing the rock failure criterion parameter of $m_{i}$ increases the strength of rocks, which is not the case in reality.

Also, it was found that under higher confining pressures, the destructive cracks in the rocks are smaller, which could lead to ductile behaviour in the rock. From the results, it was found that at low values of confining pressures, the number of developed cracks in all three different rock types are almost the same at the peak strength value, however at the elastic range of the applied load, the number of cracks which developed in sandstone are significantly greater than the other rocks, nearly six times. This value reduces sharply with increasing confining pressure. 


\section{Reference}

Akram, M. S., \& Sharrock, G. B. (2010): Physical and numerical investigation of a cemented granular assembly of steel spheres. International Journal for Numerical and Analytical Methods in Geomechanics, 34, 18, 1896-1934.

Asadi, M., Rasouli, V., \& Barla, G. (2012): A bonded particle model simulation of shear strength and asperity degradation for rough rock fractures. Rock Mechanics and Rock Engineering, 45, 5, 649-675. doi:10.1007/s00603-0120231-4.

Bagheripour, M. H., \& Hakimipour, R. (2009): Evaluating the efficiency of the Hoek-Brown failure criterion in predicting strength of rock mass for dam foundations and tunnels. In Proc. 1st National Conference on Engineering and Infrastructure Managements, 27-29.

Bahaaddini, M., Sharrock, G., \& Hebblewhite, B. K. (2013a): Numerical direct shear tests to model the shear behaviour of rock joints. Computers and Geotechnics, 51, 101-115. doi:10.1016/j.compgeo.2013.02.003.

Bahaaddini, M., Sharrock, G., \& Hebblewhite, B. K. (2013b): Numerical investigation of the effect of joint geometrical parameters on the mechanical properties of a non-persistent jointed rock mass under uniaxial compression. Computers and Geotechnics, 49, 206-225. doi:10.1016/j.compgeo.2012.10.012.

Bahaaddini, M., Hagan, P. C., Mitra, R., \& Hebblewhite, B. K. (2014): Scale effect on the shear behaviour of rock joints based on a numerical study. Engineering Geology, 181, 212-223. doi:10.1016/j.enggeo.2014.07.018.

Bahaaddini, M., Hagan, P. C., Mitra, R., \& Hebblewhite, B. K. (2016): Numerical study of the mechanical behaviour of non-persistent jointed rock masses. International Journal of Geomechanics, 16, 1, 04015035-040150310. doi: 10.1061/(ASCE)GM.1943-5622.0000510.

Bahaaddini, M. (2017): Effect of boundary condition on the shear behaviour of rock joints in the direct shear test. Rock Mechanics and Rock Engineering, 50, 5, 1141-1155. doi:10.1007/s00603-016-1157-z.

Bahaaddini, M., Sheikhpourkhani, A. M., \& Mansouri, H. (2019): Flat-joint model to reproduce the mechanical behaviour of intact rocks. European Journal of Environmental and Civil Engineering.1-22. Doi:10.1080/19648189.20 19.1579759

Bahrani, N., Valley, B., Kaiser, P. K., \& Pierce, M. (2011): Evaluation of PFC2D grain-based model for simulation of confinement-dependent rock strength degradation and failure processes. 45th US Rock Mechanics/Geomechanics Symposium. American Rock Mechanics Association.

Bertuzzi, R., Douglas, K., \& Mostyn, G. (2016): Comparison of quantified and chart GSI for four rock masses. Engineering Geology, 202, 24-35.

Briševac, Z., Kujundžić, T., \& Čajić, S. (2015): Current cognition of rock tensile strength testing by Brazilian test. «Rudarsko-geološko-naftni zbornik (The Mining-Geology-Petroleum Engineering Bulletin)» 30, 2, 101-128. https://doi.org/10.17794/rgn zbornik.v30i2.3649.
Calvetti, F. (2008): Discrete modeling of granular materials and geotechnical problems. European Journal of Environmental and Civil Engineering, 12, 7-8, 951-965. doi:10.1 080/19648189.2008.9693055.

Colak K, Unlu T (2004): Effect of transverse anisotropy on the Hoek-Brown strength parameter 'mi' for intact rocks. Inernational Journal of rock mechanics mining sciences, 41, 1045-1052. https://doi.org/10.1016/j.ijrmms.

Cui, Z., Sheng, Q., Leng, X., \& Ma, Y. (2019): investigation of the long-term strength of Jinping marble rocks with experimental and numerical approaches. Bulletin of Engineering Geology and the Environment. 78, 877-882. https://doi:10.1007/s10064-017-1132-2.

Feng, X., \& Jimenez, R. (2015): Estimation of deformation modulus of rock masses based on Bayesian model selection and Bayesian updating approach. Engineering Geology, 199, 19-27.

Deisman, N., Mas Ivars, D., Darcel, C., \& Chalaturnyk, R. J. (2010): Empirical and numerical approaches for geomechanical characterization of coal seam reservoirs. International Journal of Coal Geology, 82, 34, 204-212. doi: 10.1016/j.coal.2009.11.003.

Dunda, S., Hrzenjak, P., \& Kujundzic, T. (2003): Stresses and Deformability of Rock Mass upon Open Pit Exploitation of Dimension Stone. Rudarsko-geološko-naftni zbornik (The Mining-Geology-Petroleum Engineering Bulletin), $15,1,49-55$.

Gu, X., Li, W., Qian, J., \& Xu, K. (2017): Discrete element modeling of the influence of inherent anisotropy on the shear behaviour of granular soils. European Journal of Environmental and Civil Engineering, 22, 1-18. doi: 10.1080/19648189.2017.1352030.

Hama, N. A., Ouahbi, T., Taibi, S., Souli, H., Fleureau, J. M., \& Pantet, A. (2017): Relationships between the internal erosion parameters and the mechanical properties of granular materials. European Journal of Environmental and Civil Engineering, 1-13. doi:10.1080/19648189.2017. 1347526.

He, M., Zhang, Z., Zheng, J., Chen, F., \& Li, N. (2020): A New Perspective on the Constant mi of the Hoek-Brown Failure Criterion and a New Model for Determining the Residual Strength of Rock. Rock Mechanics and Rock Engineering, 53, 3953-3967.

Hoek, E., \& Brown, E. T. (1980): Empirical strength criteria for rock masses. Journal of Geotechnical Engineering Division, American Society of Civil Engineering ;(United States), 106, 1013-1035.

Hoek, E., (2007): Practical rock engineering. Institution of Mining and Metallurgy, London, 198-200.

Hoek, E., \& Martin, C. D. (2014): Fracture initiation and propagation in intact rock-a review. Journal of Rock Mechanics and Geotechnical Engineering, 6, 4, 287-300.

Hoek, E., \& Brown, E. T. (2019): The Hoek-Brown failure criterion and GSI-2018 edition. Journal of Rock Mechanics and Geotechnical Engineering, 11, 3, 445-463. https:// doi.org/10.1016/j.jrmge.2018.08.001. 
Itasca Consulting Group Inc. (2017): PFC (particle flow code in 2 and 3 dimensions), version 5.0 User's manual. Minneapolis, Minnesota.

Jafari Mohammadabadi, B., Shahriar, K., Jalalifar, H., \& Ahangari, K. (2021): An investigation on the effects of micro-parameters on the strength properties of rock. Rudarsko-geološko-naftni zbornik (The Mining-GeologyPetroleum Engineering Bulletin), 36, 1, 111-119.

Jiang, X. Y., Cui, P., \& Liu, C. Z. (2016): A chart-based seismic stability analysis method for rock slopes using Hoek-Brown failure criterion. Engineering Geology, 209, 196-208.

Jiang, M., Liao, Y., Wang, H., \& Sun, Y. (2018): Distinct element method analysis of jointed rock fragmentation induced by TBM cutting. European Journal of Environmental and Civil Engineering, 22, 1, 79-98. doi:10.1080/19648 189.2017.1385540.

Lin, H., Wang, H., Fan, X., Cao, P., \& Zhou, K. (2017): Particle size distribution effects on deformation properties of graded aggregate base under cyclic loading. European Journal of Environmental and Civil Engineering, 23, 3, 1-18. doi: 10.1080/19648189.2016.1276480.

Mas Ivars, D., Pierce, M. E., Darcel, C., Reyes-Montes, J., Potyondy, D. O., Young, R. P., \& Cundall, P. A. (2011): The synthetic rock mass approach for jointed rock mass modelling. International Journal of Rock Mechanics \& Mining Sciences, 48, 2, 219-244. doi:10.1016/j. ijrmms.2010.11.014.

Merifield, R. S., Lyamin, A. V., \& Sloan, S. W. (2006): Limit analysis solutions for the bearing capacity of rock masses using the generalised Hoek-Brown criterion. International Journal of Rock Mechanics and Mining Sciences, 43, 6, 920-937. https://doi.org/10.1016/j.ijrmms.2006.02.001

Osgoui, R. R., \& Ünal, E. (2009): An empirical method for design of grouted bolts in rock tunnels based on the Geological Strength Index (GSI). Engineering geology, 107, 3-4, 154-166.

Peng, J., Rong, G., Cai, M., Wang, X., \& Zhou, C. (2014): An empirical failure criterion for intact rocks. Rock Mechanics and Rock Engineering, 47, 2, 347-356. https://doi. org/10.1007/s00603-012-0355-6

Peng, J., Cai, M., Rong, G., Yao, M. D., Jiang, Q. H., \& Zhou, C. B. (2017): Determination of confinement and plastic strain dependent post-peak strength of intact rocks. Engineering Geology, 218, 187-196. https://doi.org/ 10.1016/j.enggeo.2017.01.018

Perras, M. A., \& Diederichs, M. S. (2014): A review of the tensile strength of rock: concepts and testing. Geotechnical and geological engineering, 32, 2, 525-546.

Potyondy, D. O., \& Cundall, P. A. (2004): A bonded-particle model for rock. International journal of rock mechanics and mining sciences, 41, 8, 1329-1364. doi:10.1016/j. ijrmms.2004.09.011.

Potyondy, D. O. (2012): A flat-jointed bonded-particle material for hard rock. 46th U.S. Rock Mechanics/Geomechanics Symposium, Chicago, USA.

Ramamurthy, T. (2001): Shear strength response of some geological materials in triaxial compression. International
Journal of Rock Mechanics and Mining Sciences, 38, 5, 683-697.

Sari, M. (2012): An improved method of fitting experimental data to the Hoek-Brown failure criterion. Engineering geology, 127, 27-35.

Saroglou, H., \& Tsiambaos, G. (2008): A modified Hoek-Brown failure criterion for anisotropic intact rock. International Journal of Rock Mechanics and Mining Sciences, 45, 2, 223-234. https://doi.org/10.1016/j.ijrmms.2007.05.004.

Shen, J., Karakus, M., \& Xu, C. (2013): Chart-based slope stability assessment using the Generalized Hoek-Brown criterion. International Journal of Rock Mechanics and Mining Sciences, 64, 210-219.

Shen, J., \& Karakus, M. (2014): Simplified method for estimating the Hoek-Brown constant for intact rocks. Journal of Geotechnical and Geoenvironmental Engineering, 140, 6, 04014025 .

Sheorey, P. R., Biswas, A., \& Choubey, V. D. (1989): An empirical failure criterion for rocks and jointed rock masses. Engineering Geology, 26, 2, 141-159.

Singh, M., Raj, A., \& Singh, B. (2011): Modified Mohr-Coulomb criterion for non-linear triaxial and polyaxial strength of intact rocks. International Journal of Rock Mechanics and Mining Sciences, 48, 4, 546-555.

Singh, M., Samadhiya, N. K., Kumar, A., Kumar, V., \& Singh, B. (2015): A nonlinear criterion for triaxial strength of inherently anisotropic rocks. Rock Mechanics and Rock Engineering, 48, 4, 1387-1405. https://doi.org/10.1007/ s00603-015-0708-z.

Song, Z., Li, M., Yin, G., Ranjith, P. G., \& Liu, C. (2019): Rock strength criterion considering the effect of hydrostatic stress on lode angle effect. Energy Science \& Engineering, 7, 4, 1166-1177. https://doi.org/10.1002/ ese3.337.

Sun, C., Chai, J., Xu, Z., Qin, Y., \& Chen, X. (2016): Stability charts for rock mass slopes based on the Hoek-Brown strength reduction technique. Engineering Geology, 214, 94-106.

Wen, T., Tang, H., Huang, L., Hamza, A., \& Wang, Y. (2021). An empirical relation for parameter mi in the Hoek-Brown criterion of anisotropic intact rocks with consideration of the minor principal stress and stress-to-weak-plane angle. Acta Geotechnica, 16, 2, 551-567. https://doi.org/10.1007/ s11440-020-01039-y.

Wu, Z., Fan, L., Liu, Q., \& Ma, G. (2017): Micro-mechanical modeling of the macro-mechanical response and fracture behaviour of rock using the numerical manifold method. Engineering Geology, 225, 49-60. http://dx.doi.org/ 10.1016/j.enggeo.2016.08.018.

Yang, S. Q., \& Huang, Y. H. (2018): Failure behaviour of rocklike materials containing two pre-existing unparallel flaws: an insight from particle flow modeling. European Journal of Environmental and Civil Engineering, 22, 1, 57-78. doi: 10.1080/19648189.2017.1366954.

Yoshida, N., Morgenstern, N. R., \& Chan, D. H. (1990): A failure criterion for stiff soils and rocks exhibiting softening. Canadian Geotechnical Journal, 27, 2, 195-202. 
Yudhbir, Y., Lemanza, W., \& Prinzl, F. (1983): An empirical failure criterion for rock masses. In 5th ISRM Congress. International Society for Rock Mechanics and Rock Engineering.

Zhang, Y., \& Stead, D. (2014): Modelling 3D crack propagation in hard rock pillars using a synthetic rock mass approach. International journal of rock mechanics and mining sciences, 72, 199-213.
Zuo, J. P., Li, H. T., Xie, H. P., Ju, Y., \& Peng, S. P. (2008): A nonlinear strength criterion for rock-like materials based on fracture mechanics. International Journal of Rock Mechanics and Mining Sciences, 45, 4, 594-599.

Zuo, J., Liu, H., \& Li, H. (2015): A theoretical derivation of the Hoek-Brown failure criterion for rock materials. Journal of Rock Mechanics and Geotechnical Engineering, 7, 4, 361-366.

\section{SAŽETAK}

\section{Numerička i eksperimentalna istraživanja mehanizma loma stijene te ovisnosti toga procesa o Hoek-Brownovu kriteriju loma $\mathbf{m}_{\mathrm{i}}$}

Mehanizam loma stijene jedno je od najvažnijih pitanja u mehanici i inženjerstvu stijena te je ključno u analizi stabilnosti raznih struktura. Za različite kriterije loma predloženi su različiti mehanizmi odgovorni za takav proces. Jedan od najčešće korištenih kriterija kojim se opisuje lom stijena jest Hoek-Brownov kriterij, u kojemu postoji varijabla zvana m, koja je vrlo važna kod ocjene tim kriterijem. Zbog važnosti provođenja opsežnih studija o prilagođavanju te varijable $u$ prikazanim istraživanjima ona je određena izvođenjem serije eksperimentalnih ispitivanja troosne tlačne čvrstoće i numeričke simulacije u PFC-2D kodu. Time je istražen učinak vrijednosti $m_{i}$ na lom stijene i rast pukotina različitih stijena. Na temelju rezultata utvrđeno je kako je utjecaj varijable $m_{i}$ na lom različitih vrsta stijena varijabilan, a najveći je učinak na vršnu čvrstoću stijena. Također, utvrđeno je da su pod većim bočnim pritiscima razarajuće pukotine u stijenama manje (uspoređeno s prethodnim testom), a kao rezultat pokazuju više duktilno ponašanja.

\section{Ključne riječi:}

mehanizam loma, Hoek-Brownova varijabla $\mathrm{m}_{\mathrm{i}}$, troosna tlačna čvrstoća, PFC-2D

\section{Author's contribution}

Sina Salajegheh (Ph.D. student): author and performed numerical tests and laboratory experiments. Shahriar (Full Professor): interpreted and analysed the numerical and laboratory results. Jalalifar (Full Professor): created the ideation and monitored the execution of work from the beginning to the end. Ahangari (Assistance Professor): assisted in writing and in the history of literature. 